\title{
Journal Entries As Tools For Financial Statement Disclosure Of Pension Reporting And Other Comprehensive Income
}

\author{
Robert E. Jackson, Georgia Southern University, USA
}

L. Dwight Sneathen Jr., Georgia Southern University, USA

\begin{abstract}
This instructional tool draws a linkage between the journal entries required to record the activity of a defined benefit pension plan and the disclosures required under authoritative guidance. The quarterly and year-end adjusting entries are presented and linked to the financial statements and supplemental financial disclosures. These entries directly tie to amounts reflected in those disclosures to provide a more comprehensive analysis of the reporting process. The resulting analysis is beneficial for the understanding of pension accounting and the reporting of accumulated other comprehensive income.
\end{abstract}

Keywords: Financial Statement Disclosures; Other Comprehensive Income; Pension Reporting; FASB ASC No. 220; FASB ASC No. 715

\section{INTRODUCTION}

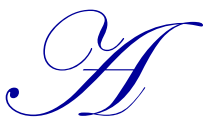

ccounting for defined benefit pension plans incorporates a number of complex recognition and disclosure issues. The resources available to accounting educators are simplified examples that focus on providing the information necessary for the year-end financial statements with little exposition of the associated disclosures. ${ }^{1}$ Changes in the reporting requirements for pension plans and accumulated other comprehensive income (AOCI) add to the gap between the material presented in traditional textbooks and real world accounting situations.

The tool we provide here is designed to integrate a real world set of quarterly and adjusting journal entries for a defined benefit pension plan with the required financial statement and disclosure presentation. These entries are designed to prepare quarterly and annual financial statements while providing the specific amounts for supplemental disclosures required by authoritative guidance.

Jackson, Sneathen and Veal (2012) presented a worksheet approach to pension accounting that looked at both the employer and the plan side of the pension environment. The worksheet approach displayed the impact of transactions on key accounts, but did not elaborate on the journal entries related to those transactions. Further, they did not elaborate on the presentation of the related items in the Statement of Comprehensive Income or any required supplemental disclosures. Accounting Standard Update 2013-02 (Accounting Standards Codification section 220) and 2017-07 (Accounting Standards Codification section 715) changed reporting requirements specifically related to disclosures for net periodic pension cost and reclassification adjustments in other comprehensive income (OCI). This tool was a natural next step in addressing these required changes.

\footnotetext{
${ }^{1}$ For examples see Kieso, Weygandt and Warfield (2016), Intermediate Accounting; Spiceland, Nelson, and Thomas (2018), Intermediate
} Accounting.

Copyright by author(s); $\underline{\mathrm{CC}-\mathrm{BY}}$ 


\section{FINANCIAL REPORTING REQUIREMENTS}

Our focus here is on the disclosures that are required and how we can develop the journal entries to reconcile with the amounts included in those disclosures. Accounting Standards Codification (ASC) section 220 (Comprehensive Income) deals with the presentation of accumulated other comprehensive income in the Statement of Comprehensive Income and the required disclosures relating to the components of OCI and AOCI. Accounting Standards Update 2013-02 changed reporting requirements for AOCI. The following items related to the accumulated comprehensive income items need to be disclosed: changes in the accumulated balances for each component of AOCI before reclassification, amounts reclassified in the current period out of AOCI, the effects on net income of significant amounts reclassified out of each component of AOCI.

ASC 715 (Compensation-Retirement Benefits) addresses the accounting requirements surrounding a defined benefit pension plan. This includes the measurement of net periodic pension cost and presentation in the Income Statement, Statement of Comprehensive Income, Statement of Shareholder's Equity, Statement of Financial Position, and supplemental footnote disclosures. Accounting Standards Update 2017-07 changed the presentation of net periodic pension cost in the Income Statement separating the service cost, which should be combined with other employee related compensation costs, and other elements of net periodic pension cost which are listed in other income/(expense) outside a subtotal for operating income.

The disclosures required by ASC 715 include information on the benefit obligation, plan assets, and net periodic pension cost. These disclosures are normally part of the pension footnote to the financial statements, and may address dollar amounts that are not reflected on the books of the employer. Because the employer does not have control over the plan assets there are questions about whether they should be included as an asset on the books of the employer. When they are recorded the pension liability will reflect the full Projected Benefit Obligation. The net of the Projected Benefit Obligation and the net assets will equal the Funded Status of the plan. When the plan assets are not included on the employer's books the pension liability reflects the unamortized portion of the prior service cost and unrealized gains/(losses) netted out against the difference between the net periodic pension cost and the contributions to the plan by the employer.

\section{JOURNAL ENTRIES AND FINANCIAL STATEMENT DISCLOSURES}

\section{Year 1}

Plan Adoption and Journal Entries During the Year

To fully understand the structure of the journal entries, it is helpful to see the entire process from plan adoption to quarterly and year-end adjusting entries. At the time a plan is adopted, an actuarial report would be necessary to assess the prior service cost that must be recognized. According to ASC 715 this would require the recognition of a noncurrent pension liability and other comprehensive income recognition of the unamortized prior service cost.

Moving forward, an estimate of the net periodic pension cost would be required for quarterly adjusting entries. The quarterly entries would allocate the service cost component of estimated net periodic pension cost to the same line item as other compensation costs arising from services rendered by the pertinent employees during the period. The other components of estimated net periodic pension cost are recognized in other income/(expense) outside the subtotal of income from operations. The compensation costs could be capitalized as part of inventory, or expensed as part of operating expenses. We will classify these in a single general account Compensation Costs, while the other components will be combined in Pension Expense.

For expositional purposes we recognize the liability resulting from the defined benefit pension plan in two accounts. Entries for net periodic pension cost and contributions to the pension plan are offset in Prepaid (Accrued) Pension Cost. Separately the unamortized portion of the prior service cost and any unrealized gains/(losses) are accumulated in Pension Liability (Non-Current). These two accounts, when combined, will reflect the funded status of the plan. 
The following amounts would be necessary for the preparation of journal entries during the year, and would be provided through an actuarial report:

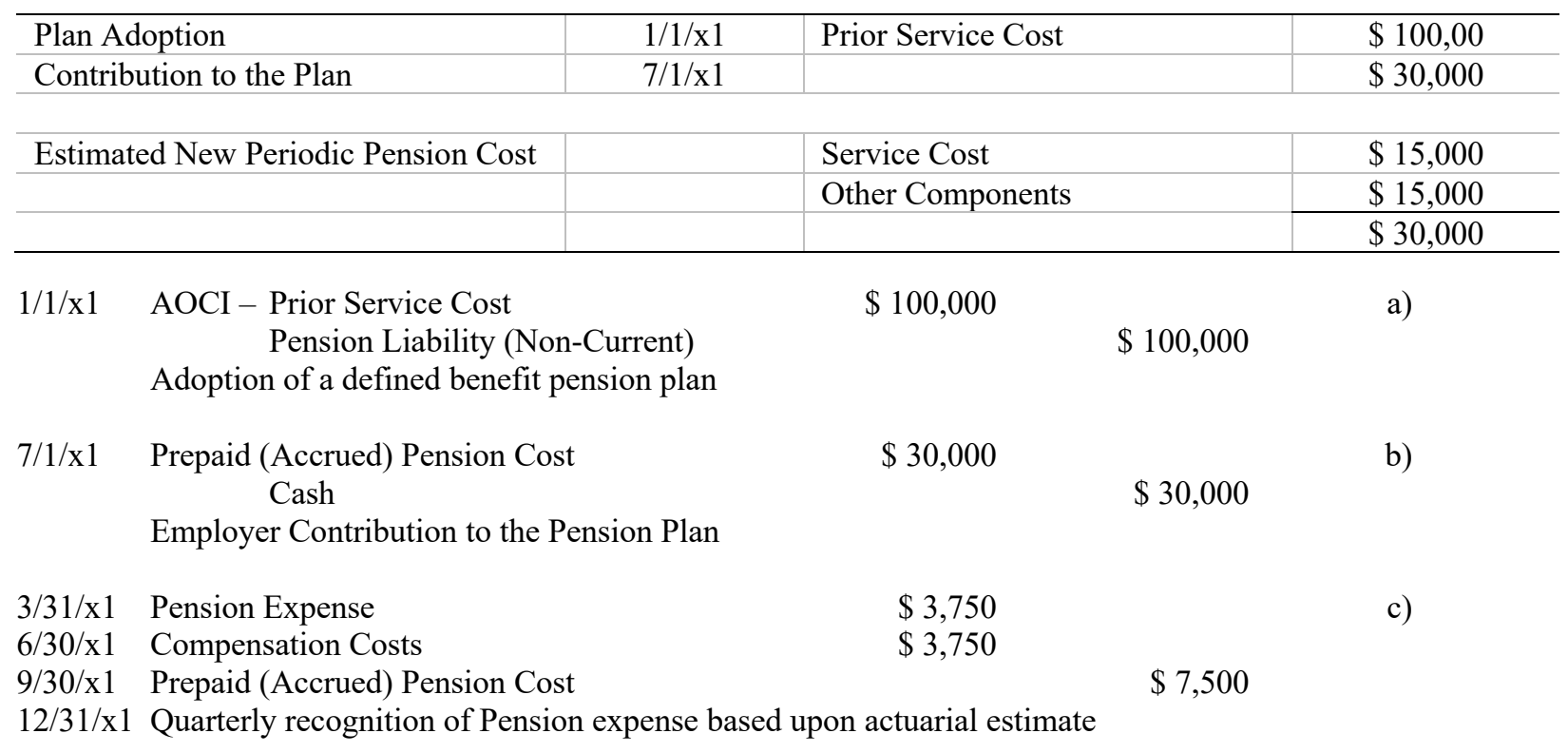

The actuarial estimate was used to prepare four quarterly entries (c). Any difference between the estimated and actual net periodic pension cost will be addressed in the year-end adjusting entries.

\section{Year-End Adjusting Entries}

At the end of the year a final actuarial report would provide the following data for adjusting entries:

\begin{tabular}{l|c|l}
\hline Components of New Periodic Pension Cost & & \\
\hline Service Cost & $\$ 15,000$ & \\
\hline Interest Cost & 8,000 & (based upon an 8\% rate) \\
\hline Expected Return on Plan Assets & $(1,200)$ & (based upon an 8\% rate) \\
\hline Amortization of Prior Service Cost & 10,000 & (estimated service life is 10 years) \\
\hline Net Periodic Pension Cost & $\$ 31,800$ & \\
\hline Actual Return on Plan Assets & $\$ 1,200$ & Tax Rate 25\% \\
\hline
\end{tabular}

Based upon the actuarial report the following adjusting entries are required:
12/31/x1 Pension Expense
$\$ 1,800$
d)
Prepaid (Accrued) Pension Cost

$\$ 1,800$

Adjustment to reflect differences between estimated and actual net periodic pension cost

Pension Liability (Non-Current)

AOCI - Prior Service Cost

Amortization of Prior Service Cost

Deferred Income Tax

AOCI - Prior Service Cost

Recognition of deferred taxes (tax rate of $25 \%$ )
$\$ 10,000$

$\$ 22,500$

$\$ 22,500$ e)

$\$ 10,000$

f) 
Because the net periodic pension cost should be allocated between Compensation Cost and Pension Expense we need to review the amounts that were recorded through the quarterly journal entries. A total of $\$ 30,000$ was recognized with $\$ 15,000$ of that allocated to service cost and therefore Compensation Cost. This amount matches the year-end actuarial report so the difference between the estimate and the actual cost is attributed to Pension Expense in entry d).

The recognition of deferred taxes in entry f) results in the AOCI component being valued at its net of tax amount. We will leave this amount at its net of tax value as we move into Year 2. Since we are not carrying the plan assets on the books of the employer we do not record a journal entry for the actual return on plan assets which is $\$ 1,200$ for $\mathrm{x} 1$. This information will be reflected in the disclosures below.

\section{Year-End Financial Reporting}

The journal entries above are designed to map into the financial reporting requirements within the Statement of Comprehensive Income and related disclosures. We will present the Statement of Comprehensive Income in a two part format beginning with Net Income. For presentation, we will use \$150,000 for x1 Net Income.

\section{Statement of Comprehensive Income}

For the year ended $12 / 31 / \mathrm{x} 1$

Net income

$\$ 150,000$

Other comprehensive income before reclassification

Prior Service Cost at Plan Adoption

Amount reclassified from accumulated other comprehensive income

Amortization of Prior Service Cost

Other Comprehensive Income Before Tax

Deferred Income Tax

Other Comprehensive Income After Tax

$(100,000)$

\begin{tabular}{r}
10,000 \\
\hline$(90,000)$ \\
22,500
\end{tabular} a)

e)

f)

Comprehensive Income

Here there are three journal entry references that map into the Statement of Comprehensive Income including the prior service cost at plan adoption (a), the year-end adjusting entries for the amortization of prior service cost (e), and the recognition of deferred taxes (f). The dollar amounts reflected in the journal entries are equal to the numbers reflected in the Statement of Comprehensive Income.

The related disclosure for the Statement of Comprehensive Income would present the changes in AOCI balances and the reclassification of any AOCI amounts. This disclosure would also meet the requirements of ASC 715 including the amounts in AOCI that have not yet been recognized as components of net periodic benefit cost. ASC 220 allows for presentation before-tax and net of tax. We provide a reconciliation of both figures.

Notes to the Financial Statement

$$
\begin{gathered}
\text { Changes in AOCI by Component } \\
\text { For the year ended } 12 / 31 / x 1 \\
\text { Defined Benefit Pension Items }
\end{gathered}
$$

\begin{tabular}{|c|c|c|}
\hline Before Tax & Tax & Net of Tax \\
\hline \$ - & $\$$ & $\$$ \\
\hline 100,000 & $(25,000)$ & 75,000 \\
\hline
\end{tabular}

Beginning Balance

Other comprehensive income before classifications

Prior Service Costs in the current period

Amount reclassification from accumulated other comprehensive income

Amortization of Prior Service Cost

Ending Balance

\begin{tabular}{c}
$(10,000)$ \\
\hline 90,000 \\
\hline \hline
\end{tabular}

\begin{tabular}{ccc}
$\frac{2,500}{22,500}$ & $\frac{(7,500)}{\$ 67,500}$ \\
\hline
\end{tabular}

Copyright by author(s); $\underline{\text { CC-BY }}$ 
According to ASC 715 the disclosures related to the defined benefit pension plan include a reconciliation of the benefit obligation, the fair value of the plan assets, the amount of net benefit cost recognized, the funded status of the plan, and the amounts recognized in the Statement of Financial Position. These would normally be included in the pension footnote. The actual return and expected return for Year 1 were equal so there is no gain or loss recognition required.

\begin{tabular}{lr}
\multicolumn{2}{c}{ Change in Benefit Obligation } \\
\hline Beginning & $\$-$ \\
Prior service cost at plan adoption & 100,000 \\
Service Cost & 15,000 \\
Interest Cost & 8,000 \\
Ending & $\$ 123,000$ \\
\hline
\end{tabular}

\begin{tabular}{lr}
\multicolumn{2}{c}{ Change in Plan Assets } \\
\hline Beginning & $\$-$ \\
Contribution to Plan & 30,000 \\
Benefits Paid & - \\
Actual Return & 1,200 \\
Ending & $\$ 21,200$ \\
\hline
\end{tabular}

\begin{tabular}{lr}
\multicolumn{2}{c}{ Net Periodic Benefit Cost } \\
\hline Service Cost & $\$ 15,000$ \\
Insert Cost & 8,00 \\
Expected Return & $(1,200)$ \\
Amortization of PSC & 10,000 \\
Net Gain/Loss & - \\
Net Periodic $\quad$ Pension Cost & $\$ 31,800$ \\
\hline
\end{tabular}

\begin{tabular}{lr}
\multicolumn{2}{c}{ Funded Status } \\
\hline $\begin{array}{l}\text { Plan Assets } \\
\text { Projected Benefit Obligation } \\
\text { Over (Under) Funded }\end{array}$ & $\$ 31,200$ \\
& $(123,000)$ \\
\hline $\begin{array}{l}\$(91,800) \\
\text { Balance Sheet Accounts }\end{array}$ \\
$\begin{array}{l}\text { Prepaid (Accrued) Pension Cost } \\
\text { Pension Liability (Non-Current) }\end{array}$ & $\begin{array}{r}\$(1,800) \\
(90,000)\end{array}$ \\
\hline \hline
\end{tabular}

Each of the numbers presented in the financial statement disclosures directly ties to a journal entry or an amount in the actuarial report. It is important to highlight the total of the two Balance Sheet accounts are equal to the Funded Status of the Pension Plan. The Prepaid/(Accrued) Pension Cost is the net of the recognized net periodic pension cost and the employer's contribution to the plan.

Year 2

Journal Entries During the Year

The following information would be necessary to prepare the quarterly entries for the plan.

\begin{tabular}{l|l|r}
\hline Contribution to the Plan & \multicolumn{1}{|c}{$12 / 31 / \mathrm{x} 2$} & $\$ 30,000$ \\
\hline Estimated Net Periodic Pension Cost & Service Cost & $\$ 18,500$ \\
\hline & Other Components & 18,500 \\
\hline & & $\$ 37,000$ \\
\hline
\end{tabular}

$\begin{array}{llll}3 / 31 / \mathrm{x} 2 & \text { Pension Expense } & \$ 4,625 & \mathrm{~g}) \\ 6 / 30 / \mathrm{x} 2 & \text { Compensation Costs } & \$ 4,625 & \end{array}$

$\begin{array}{ll}9 / 30 / \mathrm{x} 2 & \text { Prepaid (Accrued) Pension Cost } \\ 12 / 31 / \mathrm{x} 2 & \text { Quarterly recognition of Pension expense based upon actuarial estimate }\end{array}$

$\begin{array}{ccc}12 / 31 / x 2 & \text { Prepaid (Accrued) Pension Cost } \\ \text { Cash } & \$ 40,000 & \$ 40,000\end{array}$

The quarterly entries for net periodic pension cost are allocated in Year 2 as they were in Year 1. The actuarial estimate provided the service cost component of the annual estimate which is used to derive the journal entry allocation in entry g). 
Year-End Adjusting Entries

At the end of the year a final actuarial report would provide the following data for adjusting entries:

\begin{tabular}{l|c|l}
\hline Components of Net Periodic Pension Cost & \multicolumn{2}{|l}{} \\
\hline Service Cost & $\$ 18,000$ & (based upon an 8\% rate) \\
\hline Interest Cost & 9,840 & (based upon an 8\% rate) \\
\hline Expected Return on Plan Assets & $(2,496)$ & \\
\hline Amortization of Prior Service Cost & 10,000 & \\
\hline Net Periodic Pension Cost & $\$ 35,344$ & \\
\cline { 2 - 2 } & \multicolumn{2}{|c}{ (estimated service life is 10 years) } \\
\hline Actual Return on Plan Assets & $\$ 2,996$ & \\
\hline Benefits Paid & $\$ 1,000$ & Tax Rate 25\% \\
\hline
\end{tabular}

Based upon the actuarial report the following adjusting entries are required:

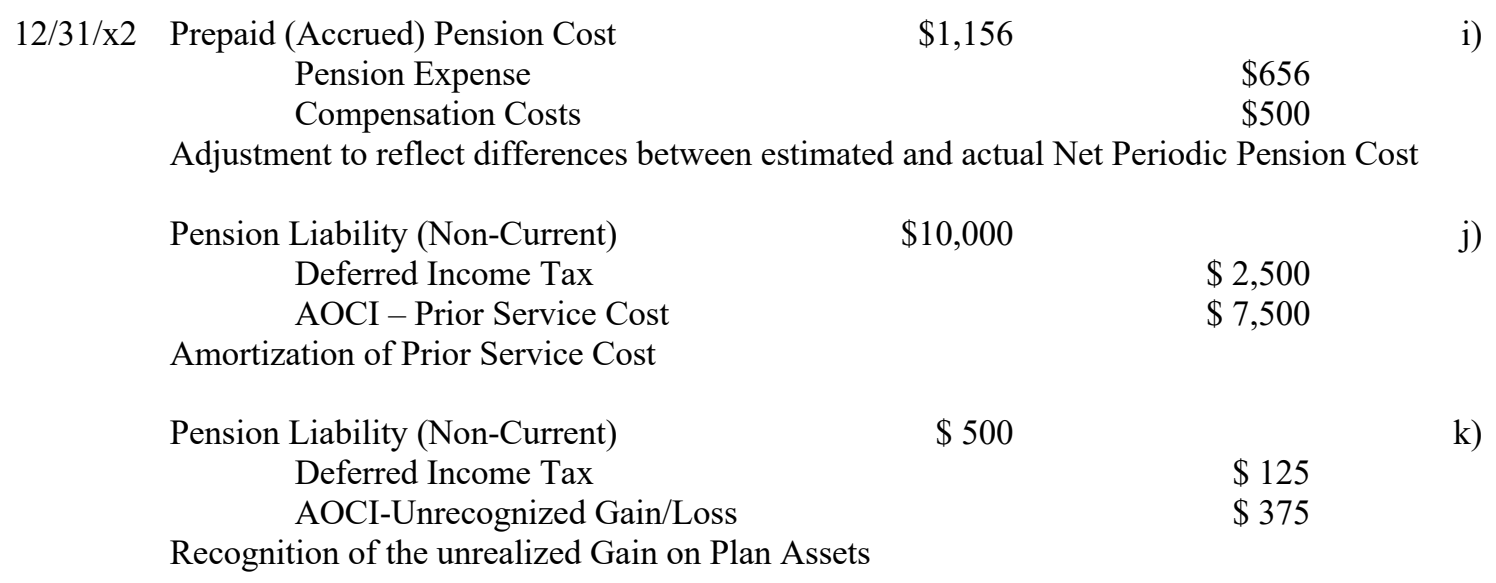

Again we need to review the difference between the estimated and actual net periodic pension cost and the allocation between Compensation Cost and Pension Expense. A total of $\$ 37,000$ was recognized with $\$ 18,500$ of that allocated to service cost and therefore Compensation Cost. This amount exceeds the year-end actuarial report requiring an adjustment to Compensation Cost, with the remaining difference between the estimate and the actual cost entered into Pension Expense in entry i).

Entry j) reflects the fact that the AOCI component was carried at its net of tax amount from $x 1$. The difference between the expected return and the actual return on plan assets results in the recognition of an unrecognized gain on plan assets in entry k). There is no entry for Benefits Paid since the Plan Assets are not recognized on the books of the employer. The deferred taxes are not a separate entry for Year 2 due to the net of tax presentation.

\section{Year-End Financial Reporting}

Once again, we will start with the Statement of Comprehensive Income followed by required disclosures. For presentation, we will use $\$ 200,000$ for $\times 2$ Net Income. 
Statement of Comprehensive Income

For the year ended $12 / 31 / \mathrm{x} 2$

Net income

$\$ 200,000$

Other Comprehensive Income

Other comprehensive income before reclassification

Unrealized Gain in the Current Period

Amount reclassified from accumulated other comprehensive income Amortization of Prior Service Cost

Other Comprehensive Income Before Tax

Deferred Income Tax

Other Comprehensive Income After Tax

Comprehensive Income

$\begin{aligned} 500 & \mathrm{k}) \\ \frac{10,000}{10,500} & \text { j) } \\ (\underline{2,625}) & \mathrm{j})+\mathrm{k})\end{aligned}$

$\begin{array}{r}7,875 \\ \hline \underline{\underline{\$ 207,875}}\end{array}$

There are two journal entries that map into the presentation including the year-end adjusting entry for the amortization of prior service cost (j), the unrecognized gain on plan assets (k), and the net effect of the deferred taxes from the two entries.

Notes to the Financial Statement

Changes in AOCI by Component

For the period ended 12/31/x2

Defined Benefit Pension Items

Beginning Balance

$\frac{\text { Before Tax }}{\$ 90,000} \quad \frac{\text { Tax }}{\$(22,500)} \quad \frac{\text { New of Tax }}{\$ 67,500}$

Other comprehensive income before reclassification

Unrealized Gain on Plan Assets

125

375

Amount reclassification from accumulated other comprehensive income

Amortization of Prior Service Costs

\begin{tabular}{|c|c|c|}
\hline$(10,000)$ & 2,500 & $(7,500)$ \\
\hline$\$ 79,500$ & $\$(19,875)$ & $\$ 59,625$ \\
\hline
\end{tabular}

The net of tax amounts would match the amounts carried in the Statement of Financial Position.

Subsequent disclosures would normally be part of the pension footnote. 


\begin{tabular}{|c|c|c|c|}
\hline \multicolumn{2}{|l|}{ Change in Benefit Obligation } & \multicolumn{2}{|l|}{ Change in Plan Assets } \\
\hline Beginning & $\$ 123,000$ & Beginning & $\$ 31,200$ \\
\hline Service Cost & 18,000 & Contribution to Plan & 40,000 \\
\hline Interest Cost & 9,840 & Benefits Paid & $(1,000)$ \\
\hline Benefits Paid & $(1,000)$ & Actual Return & 2,996 \\
\hline Ending & $\$ 149,840$ & Ending & $\$ 73,196$ \\
\hline \multicolumn{2}{|l|}{ Net Periodic Benefit Cost } & \multicolumn{2}{|l|}{ Funded Status } \\
\hline Service Cost & $\$ 18,000$ & Plan Assets & $\$ 73,196$ \\
\hline Interest Cost & 9,840 & Projected Benefit Obligation & $(149,840)$ \\
\hline Expected Return & $(2,496)$ & Over (Under) Funded & $\$(76,644)$ \\
\hline Amortization of PSC & 10,000 & & \\
\hline Net Gain/Loss & - & Balance Sheet Accounts & \\
\hline Net Periodic & & Prepaid (Accrued) Pension Cost & $\$ 2,856$ \\
\hline \multirow[t]{2}{*}{ Pension Cost } & $\$ 35,344$ & Pension Liability (Non-Current) & $(79,500)$ \\
\hline & & & $\$(76,644)$ \\
\hline
\end{tabular}

The amounts recognized in the journal entries directly tie to the financial statements and subsequent disclosures. Once again, the net of the Balance Sheet accounts is equal to the Funded Status of the pension plan.

\section{CONCLUSION}

This paper addressed the limited textbook approach available to faculty and students for the presentation and reporting of pension plan activity in financial statements. Textbooks currently focus on the activity in the net benefit obligation and the related assets set aside to pay that obligation. This paper focuses instead on the required disclosures and the net pension asset/(liability). First, the journal entries reflect the fact that information becomes available at different times during the reporting period. Second, the journal entries are used to develop the information necessary to properly report specific amounts for other comprehensive income. This provides a connection between the pension reporting requirements in other comprehensive income and the recording of pension plan activity with a view toward the net pension asset/(liability) on the company's financial statements. Once this approach is understood for pensions, it can be related to the reporting of the other components of other comprehensive income.

\section{AUTHOR BIOGRAPHIES}

Robert E. Jackson is a CPA and an Assistant Professor of Accounting at Georgia Southern University, Statesboro, Georgia USA. Prior to entering academia, he spent over twenty years in the practice of public accountancy in Florida. His research interests include corporate governance, corporate finance, and professional regulation. E-mail: rjackson@georgiasouthern.edu

L. Dwight Sneathen Jr. is a CPA and an Associate Professor of Accounting at Georgia Southern University, Statesboro, Georgia USA. He has experience in public accounting and private industry prior to entering academia. His research interests include topics in capital markets and auditing. E-mail: dsneathen@georgiasouthern.edu (Corresponding author) 


\section{REFERENCES}

Financial Accounting Standards Board. (2011) FASB Accounting Standards Codification section 715 - CompensationRetirement Benefits. Stamford, CT: Financial Accounting Standards Board.

Financial Accounting Standards Board. (2011) FASB Accounting Standards Codification section 220 - Comprehensive Income. Stamford, CT: Financial Accounting Standards Board.

Jackson, R. E., Sneathen, L. D. Jr., and Veal, T. R. (2012). Pension Accounting and Reporting with Other Comprehensive Income and Deferred Taxes: A Worksheet Approach. American Journal of Business Education, 5(6) 771-777.

Kieso, D. E., Weygandt, J. J., and Warfield, T. D. (2016). Intermediate Accounting, $16^{\text {th }}$ edition. New Jersey: John Wiley \& Sons, Inc. Hoboken.

Spiceland J. D., Nelson, M. W., and Thomas, W. B. (2018). Intermediate Accounting $9^{\text {th }}$ edition. New York: McGraw-Hill Companies, Inc. New York. 


\section{NOTES}

